\title{
Effects of thermally induced denaturation on technological-functional properties of whey protein isolate-based films
}

\author{
M. Schmid, ${ }^{*} \dagger^{1,2}$ B. Krimmel, ${ }^{*} \ddagger^{1}$ U. Grupa, $\ddagger$ and K. Noller ${ }^{*}$ \\ ${ }^{*}$ Fraunhofer-Institute for Process Engineering and Packaging IVV, Giggenhauser Strasse 35, 85354 Freising, Germany \\ †Technische Universität München, Chair of Food Packaging Technology, Weihenstephaner Steig 22, 85354 Freising, Germany \\ łFulda University of Applied Sciences, Department of Food Technology, Marquardstrasse 35, 36039 Fulda, Germany
}

\section{ABSTRACT}

This study examined how and to what extent the degree of denaturation affected the technological-functional properties of whey protein isolate (WPI)-based coatings. It was observed that denaturation affected the material properties of WPI-coated films significantly. Surface energy decreased by approximately $20 \%$ compared with native coatings. Because the surface energy of a coating should be lower than that of the substrate, this might result in enhanced wettability characteristics between WPI-based solution and substrate surface. Water vapor barrier properties increased by about $35 \%$ and oxygen barrier properties increased by approximately $33 \%$. However, significant differences were mainly observed between coatings made of fully native WPI and ones with a degree of denaturation of $25 \%$. Higher degrees of denaturation did not lead to further improvement of material properties. This observation offers cost-saving potential: a major share of denatured whey proteins may be replaced by fully native ones that are not exposed to energy-intensive heat treatment. Furthermore, native WPI solutions can be produced with higher dry matter content without gelatinizing. Hence, less moisture has to be removed through drying, resulting in reduced energy consumption.

Key words: whey protein isolate, degree of denaturation, water vapor transmission rate, oxygen permeability, surface energy

\section{INTRODUCTION}

Protection against negative environmental impact is the main function of food packaging (Robertson, 2013). Barrier requirements of food products depend on the composition and ingredients of the product and on their requested shelf life. Especially high amounts of unsaturated FA or oxygen-sensitive vitamins need

Received December 18, 2013.

Accepted June 1, 2014.

${ }^{1}$ These authors contributed equally to this work.

${ }^{2}$ Corresponding author: markus.schmid@ivv.fraunhofer.de protection against oxygen to enable a maximum shelf life of the products. For this reason, packages are often provided by petroleum-based oxygen-barrier polymers such as ethylene vinyl alcohol (Schmid et al., 2012). The facts that these plastic materials accumulate in the environment and derive from a finite resource have attracted interest in biopolymers (Ghanbarzadeh and Almasi, 2013). It is strongly desired that bio-based packaging materials used for replacement provide the same technological-functional properties. An alternative is to coat polymer films with whey protein, which is a byproduct of cheese production. Whey proteinbased coatings act as excellent oxygen-barrier materials that also provide suitable mechanical and water vapor barrier properties (de Wit, 2001; Schmid et al., 2012; Bugnicourt et al., 2013).

During first investigations regarding whey proteinbased films and coatings, researchers found that protein denaturation is necessary for film formation (McHugh et al., 1994). Whereas native whey proteins are globular with free thiol and hydrophobic groups buried inside the molecule, heat denaturation induces protein unfolding and the exposure of internal functional groups. Intermolecular crosslinking is promoted (de Wit, 2009). These differences in the structure of native and heat-denatured whey proteins cause different physical properties of the resulting films. Fully denatured whey protein solutions have the ability to form dense and strong films, whereas films made of native whey proteins show higher permeability for gases such as oxygen and water vapor (Schmid et al., 2013c).

Guckian et al. (2006) produced whey protein isolate (WPI)-based films with adjusted degrees of denaturation by mixing heated and unheated WPI solutions in different ratios. They found that decreasing the share of unheated WPI led to increasing film solubility and weakened tensile properties, with little effect on water vapor permeability. However, to our knowledge, no data have been reported so far on the influence of different shares of native and denatured WPI on oxygen permeability and surface energy. The objective of this study was to examine how and to what extent the de- 
gree of denaturation affects the technological-functional properties of WPI-based coated films, such as oxygen permeability, water vapor transmission rate, and surface energy.

Two other research papers about the relationship between the degree of whey protein denaturation and the temperature-time profile applied during convective drying exist so far. In those studies, single droplets of native WPI solution were dried in a compartment dryer at various temperatures (Haque et al., 2013a,b). Another study showed that no correlation exists between processing temperature and techno-functional properties of films made from ethylene vinyl acetate/ WPI compounds and explained this phenomenon with the fact that no irreversible denaturation occurred during thermoplastic processing of the material (Schmid et al., 2013a). However, no experimental work has been reported on convective drying of WPI-based coatings. Hence, the present study also investigated the dependence of the degree of denaturation of WPI-based coatings on the applied temperature-time profiles during convective drying.

\section{MATERIALS AND METHODS}

\section{Raw Materials and Chemicals}

Whey protein isolate (BiPro) with a minimum protein content (on a dry basis) of $95 \%$ (total Kjeldahl nitrogen: $\mathrm{N} \times 6.38$ ) was supplied by Davisco Foods International Inc. (Le Sueur, MN) and used to produce WPI-based coatings. Glycerol was purchased from Merck Schuchardt OHG (Hohenbrunn, Germany). It was added as a plasticizer to all film-forming solutions to overcome film brittleness. Polyethylene terephthalate (PET) of 12- $\mu \mathrm{m}$ thickness (Hostaphan RNK 12.0; Mitsubishi Polyester Film GmbH, Wiesbaden, Germany) and polytetrafluoroethylene (PTFE) of 500- $\mu \mathrm{m}$ thickness (Sahlberg GmbH \& Co. KG, Feldkirchen, Germany) were used as substrates for WPI coating application. Commercially purified bovine whey proteins such as $\alpha-\mathrm{LA}, \beta-\mathrm{LG}$ A and B, and BSA were purchased from Sigma-Aldrich Chemie GmbH (Steinheim, Germany) and applied as standards in the reversed-phase HPLC (RP-HPLC) tests; HPLC-grade water, acetonitrile, and trifluoroacetic acid (TFA) were supplied by Avantor Performance Materials B.V. (Deventer, the Netherlands), Th. Geyer GmbH \& Co. KG (Renningen, Germany), and Sigma-Aldrich Chemie $\mathrm{GmbH}$, respectively. Adjustment of $\mathrm{pH}$ was done with 0.1 $M$ hydrochloric acid (Th. Geyer GmbH \& Co. KG). Double-distilled water (Merck KGaA, Darmstadt, Germany), diiodomethane, and ethylene glycol (both from Sigma-Aldrich Chemie $\mathrm{GmbH}$ ) were applied as testing liquids during determination of surface energy. All proteins and chemicals were used as received without further purification.

\section{Formulation Preparation}

Native WPI formulations were prepared by stirring aqueous solutions of $10 \%$ (wt/wt) WPI for $30 \mathrm{~min}$ at $23^{\circ} \mathrm{C}$ and $200 \mathrm{rpm}$ using a Thermomix 31-1 electric stirrer (Vorwerk Elektrowerke GmbH \& Co. KG, Wuppertal, Germany). Denatured formulations were obtained by heat treatment of the WPI solutions at $90^{\circ} \mathrm{C}$ for 30 min using the same stirring device. After cooling down the heat-treated solutions to $23^{\circ} \mathrm{C}$, glycerol was added to all formulations ( $66.7 \%$ on a DM basis). Formulations were stirred for another $30 \mathrm{~min}$ at $200 \mathrm{rpm}$ with an electric overhead stirrer (WiseStir HS-100D; Witeg Labortechnik GmbH, Wertheim, Germany). In each stage, degassing was performed via ultrasonication using a Sonorex Digitec DT 514H ultrasonic bath (Bandelin electronic GmbH \& Co. KG, Berlin, Germany) at a frequency of $37 \mathrm{kHz}$ for $15 \mathrm{~min}$. To adjust the degree of denaturation $\left(\mathbf{D}_{\text {Den }}\right)$, heat-denatured $(\mathbf{D})$ and native (N) WPI formulations were mixed gently for $5 \mathrm{~min}$ at $23^{\circ} \mathrm{C}$ using a magnetic stirrer (MR 3001; Heidolph Instruments GmbH \& Co. KG, Schwabach, Germany) to give the following $\mathrm{D}: \mathrm{N}$ (wt/wt) ratios: 0:100, 25:75, 50:50, 75:25, and 100:0.

\section{Coating and Curing}

Whey protein isolate formulations $(\mathrm{pH}$ 7.0) were applied on PET and PTFE substrates. Corona pretreatment was used to increase their surface energy and to achieve sufficient wettability and an optimum adhesion between WPI solution and substrate surface. Corona pretreatment was done with a web speed of $3 \mathrm{~m} / \mathrm{min}$ and a generator power of $1,000 \mathrm{~W}$ using a CLNE corona treatment station (Softal Corona \& Plasma GmbH, Hamburg, Germany). A surface tension of $40 \mathrm{mN} / \mathrm{m}$ was gained for PTFE and $>44 \mathrm{mN} / \mathrm{m}$ for PET. In contrast to PET, the surface energy of PTFE sheets decreased more rapidly over time. Thus, it was possible to remove coated films from PTFE, whereas this was not possible with PET substrates.

Coatings were produced with the coating unit CUF 5 (Sumet Messtechnik Heinz Suttner, Denklingen, Germany), which has a built-in convection dryer. A wet film thickness of $64 \mu \mathrm{m}$ was applied (20-N contact pressure; $20 \mathrm{~mm} / \mathrm{s}$ actuation speed). Table 1 summarizes the drying conditions for WPI-based coatings. Lowtemperature drying at $35^{\circ} \mathrm{C}$ and $1,200 \mathrm{~s}$ was chosen for the different D: $\mathrm{N}$ ratios in order not to increase the $\mathrm{D}_{\text {Den }}$ to a greater extent (no. 1-5). These tests were 
Table 1. Composition and drying conditions of whey protein isolate (WPI)-based coatings produced from various ratios of heat-denatured (D) and native $(\mathrm{N})$ whey protein solutions

\begin{tabular}{lccc}
\hline Trial no. & $\begin{array}{c}\text { D:N ratio } \\
(\text { wt } / w t)\end{array}$ & $\begin{array}{c}\text { Temperature } \\
\left({ }^{\circ} \mathrm{C}\right)\end{array}$ & $\begin{array}{c}\text { Time } \\
(\mathrm{s})\end{array}$ \\
\hline 1 & $0: 100$ & 35 & 1,200 \\
2 & $25: 75$ & 35 & 1,200 \\
3 & $50: 50$ & 35 & 1,200 \\
4 & $75: 25$ & 35 & 1,200 \\
5 & $100: 0$ & 35 & 1,200 \\
6 & $0: 100$ & 70 & 300 \\
7 & $100: 0$ & 70 & 300 \\
8 & $0: 100$ & 105 & 300 \\
9 & $100: 0$ & 105 & 300 \\
10 & $0: 100$ & 140 & 300 \\
11 & $100: 0$ & 140 & 300 \\
\hline
\end{tabular}

done to examine the influence of a given $\mathrm{D}_{\mathrm{Den}}$ on the technological-functional properties of WPI-based coatings. Additionally, higher drying temperatures (70, 105, and $140^{\circ} \mathrm{C}$ for $300 \mathrm{~s}$ ) were applied to fully native WPI formulations (D:N = 0:100; no. 6, 8, and 10) and fully denatured controls ( $\mathrm{D}: \mathrm{N}=100: 0$; no. 7, 9, and 11). These tests were performed to determine the influence of the applied temperature-time profile during convective drying on the $\mathrm{D}_{\text {Den }}$. Temperature-time profiles were considered adequate, as the equilibrium moisture content (EMC) was between 10 and $14 \%$. Coatings with an EMC in this range showed sufficient surface dryness and handling properties. All coatings were stored in a climate cabinet at $23^{\circ} \mathrm{C}$ and $50 \%$ relative humidity (RH) for $7 \mathrm{~d}$.

\section{Total Soluble Matter Measurement}

The initial dry weight of a coating was obtained using an MA35 moisture analyzer (Sartorius AG, Göttingen, Germany). A coating of about $0.5 \mathrm{~g}$ was removed from the PTFE substrate and placed into a tared infrared sample dish made of aluminum. Afterward, the sample was dried at a temperature of $105^{\circ} \mathrm{C}$ until the weight remained constant. The water content was given in percentage (wt/wt), from which the initial dry weight could be calculated.

Coatings of about $0.1 \mathrm{~g}$ were weighed to the nearest $0.0001 \mathrm{~g}$. Each sample was immersed in $50 \mathrm{~mL}$ of deionized water and agitated with a magnetic stirrer for $24 \mathrm{~h}$ at $23^{\circ} \mathrm{C}$ and $400 \mathrm{rpm}$. The solutions were filtered through Whatman grade 589/1 filter paper (GE Healthcare GmbH, Solingen, Germany) with a pore size of 12 to $25 \mu \mathrm{m}$. The initial dry weights of the filters were determined using a Kelvitron T6120 drying cabinet (Impexron GmbH, Pfullingen, Germany), where filters were dried at $105^{\circ} \mathrm{C}$ for $24 \mathrm{~h}$. After cooling down in a desiccator (Duran Group GmbH, Wertheim/Main,
Germany) for 15 min at $23^{\circ} \mathrm{C}$, initial dry weights were obtained using an analytical balance (I702; Sartorius $A G)$. Filters with residual coating material were placed into the drying cabinet. The final dry weights of the coatings were determined by subtracting the initial dry weights of the filters from the weights of dried filters and residual coatings. The percentage of total soluble matter (TSM) of the coatings was calculated from the following equation (Pérez-Gago et al., 1999):

$$
\mathrm{TSM}=\frac{\mathrm{W}-\mathrm{W}_{0}}{\mathrm{~W}} \times 100 \%,
$$

where $\mathrm{W}$ is the initial dry weight of a coating and $\mathrm{W}_{0}$ is the final dry weight of a coating after immersing in water, both given in grams. For every sample, 3 determinations were performed.

\section{Determination of the $D_{D e n}$ Using RP-HPLC}

Analysis of native whey proteins was done by RPHPLC. The WPI-based coatings were removed from PTFE substrates and dissolved in deionized water to whey protein concentrations of $0.1 \%$ (wt/wt). The required amount of coating was calculated by the following equation:

$$
\mathrm{W}_{\mathrm{F}}=\frac{\mathrm{W}_{\mathrm{X}}}{\mathrm{f}_{\mathrm{P}} \times(1-\mathrm{X})},
$$

where $\mathrm{W}_{\mathrm{F}}$ is the coating weight in grams, $\mathrm{W}_{\mathrm{X}}$ is the desired whey protein weight in grams, $f_{P}$ is the fraction of whey protein in the DM in grams per gram, and $\mathrm{X}$ is the moisture content in the coating in grams per gram. The solutions were stirred for $24 \mathrm{~h}$ at $23^{\circ} \mathrm{C}$ and $400 \mathrm{rpm}$. Subsequently, the $\mathrm{pH}$ of the solutions was adjusted to 4.6 (whey protein isoelectric point) by adding $0.1 \mathrm{M} \mathrm{HCl}$ (Parris and Baginski, 1991; Anandharamakrishnan et al., 2008; Haque et al., 2013a,b). At this pH value, the WPI remains in a native state and does not precipitate unless it is irreversibly denatured (Pelegrine and Gasparetto, 2005). The solutions were held for 30 min. Throughout this period, the $\mathrm{pH}$ was corrected to 4.6 if necessary. All samples $(2 \mathrm{~mL})$ were centrifuged at $11,000 \times g$ for $10 \mathrm{~min}$ at $23^{\circ} \mathrm{C}$ using a MiniSpin centrifuge (Eppendorf AG, Hamburg, Germany) to remove any insoluble material. Prior to HPLC, the supernatant was collected and filtered using $0.45-\mu \mathrm{m}$ syringe filters (Chromafil RC-45/15; Macherey-Nagel GmbH \& Co. KG, Düren, Germany). Reversed-phase HPLC was carried out on a Zorbax 300SB-C18 reversed-phase column (Agilent Technologies Sales \& Services GmbH \& Co. KG, Waldbronn, Germany) containing an oc- 
tadecylsilane (ODS) stationary phase $(5 \mu \mathrm{m}, 300 \AA$, $150 \times 4.6-\mathrm{mm}$ i.d.). A guard column with the same filling $(12.5 \times 4.6-\mathrm{mm}$ i.d. $)$ was used. The HPLC instrument was purchased from Thermo Fisher Scientific Inc. (Waltham, MA). It consisted of a Dionex P680 binary gradient pump with high-pressure mixer, a Dionex ASI-100 autosampler, and a Dionex UltiMate 3000 RS detector (Dionex Corp., Sunnyvale, CA). Additionally, a Gastorr BG-24 degasser (Flom Co. Ltd., Tokyo, Japan) was connected. Gradient elution was done with a modification of the method described by Ferreira and Caçote (2003). A mixture of 2 solvents was used. Eluent A consisted of $0.1 \%$ TFA and $99.9 \%$ water ( vol/vol). Eluent B contained $0.1 \%$ TFA, $19.98 \%$ water, and $79.92 \%$ acetonitrile ( $\mathrm{vol} / \mathrm{vol})$. The elution gradient was set as follows: 0 to 11 min: 45 to $56 \%$ B; 11 to 15 min: 56 to $57.6 \%$ B; 15 to 16 min: 57.6 to $45 \% \mathrm{~B}$; and $3 \mathrm{~min}$ for column re-equilibration. The temperature of the column and the flow rate of the solvent were maintained at $40^{\circ} \mathrm{C}$ and $1 \mathrm{~mL} / \mathrm{min}$, respectively. The injection volume of the sample was $40 \mu \mathrm{L}$. Detection was done at a wavelength of $215 \mathrm{~nm}$. Reversed-phase HPLC was carried out in triplicate for each sample. The $\mathrm{D}_{\text {Den }}$ was calculated by the following equation, as suggested by Parris and Baginski (1991):

$$
\mathrm{D}_{\text {Den }}=\frac{\sum \mathrm{A}_{\text {control }}-\sum \mathrm{A}_{\text {treat }}}{\sum \mathrm{A}_{\text {control }}} \times 100 \%,
$$

where $\Sigma \mathrm{A}_{\text {control }}$ is the sum of peak areas of whey protein fractions of a native control sample and $\Sigma \mathrm{A}_{\text {treat }}$ is the sum of peak areas of whey protein fractions of a heattreated sample. Whey protein fractions were identified by means of pure native standard proteins (BSA, $\alpha-\mathrm{LA}$, $\beta$-LG A, and $\beta$-LG B).

\section{Film Thickness Measurement}

Film thicknesses of WPI-based coatings were measured by the Precision Thickness Gauge FT3 (Rhopoint Instruments Ltd., Bexhill-on-Sea, UK) at 5 different positions. Measurement conditions were $23^{\circ} \mathrm{C}$ and $50 \% \mathrm{RH}$. The thickness of a coating was determined by subtracting the thickness of the substrate from the overall film thickness. Arithmetic averages were used to determine the water vapor transmission rate (WVTR) and oxygen permeability (OP).

\section{WVTR Measurement}

The WVTR of WPI-coated PET was determined according to the Deutsches Institut für Normung standard (DIN, 2001) at $23^{\circ} \mathrm{C}$ and $85 \% \rightarrow 0 \% \mathrm{RH}$. The
WVTR values $\left(\mathbf{Q}_{\text {tot }}\right)$ of multilayer films were calculated using the following equation:

$$
\mathrm{WVTR}=\mathrm{Q}_{\text {tot }}=\frac{24}{\mathrm{t}} \times \frac{\Delta \mathrm{m}}{\mathrm{A}} \times 10^{4},
$$

where $t$ is the period of time between 2 weight measurements in hours, $\Delta \mathrm{m}$ represents the weight difference between 2 weight measurements in grams, and $\mathrm{A}$ is the testing area in centimeters squared. The WVTR values were stated in grams per meter squared per day and were used for further calculation concerning the transmission rate of the WPI-based coating only. Whey protein isolate-coated PET can be considered as a laminated structure consisting of a base PET film layer and a WPI coating layer. For the 2-layer model, the following equations can be used:

$$
\begin{aligned}
& \frac{\mathrm{d}}{\mathrm{P}}=\frac{\mathrm{d}_{1}}{\mathrm{P}_{1}}+\frac{\mathrm{d}_{2}}{\mathrm{P}_{2}} ; \\
& \frac{1}{\mathrm{Q}_{\text {tot }}}=\sum \frac{\mathrm{d}_{\mathrm{i}}}{\mathrm{P}_{\mathrm{i}}}=\frac{1}{\mathrm{Q}_{1}}+\frac{1}{\mathrm{Q}_{2}},
\end{aligned}
$$

where $d$ represents the thickness of each layer $i$ in $\mu \mathrm{m}$ $\left(\mathrm{d}=\Sigma \mathrm{d}_{\mathrm{i}}\right)$ and $\mathrm{P}$ is the oxygen permeability of each layer. Subscript 1 stands for the polymer film and subscript 2 for the WPI coating. A normalization can be done for direct comparison of different materials independently of the film thickness (d) of $100 \mu \mathrm{m}\left(\mathbf{Q}_{\mathbf{1 0 0}}\right)$ using the following equation:

$$
\mathrm{Q}_{100}=\mathrm{Q}_{2} \times \frac{\mathrm{d}}{100} .
$$

A 4-fold determination was performed in all cases.

\section{OP Measurement}

The OP of WPI-coated PET was measured according to the Deutsches Institut für Normung standard (DIN, 1998) at $23^{\circ} \mathrm{C}$ and $50 \% \mathrm{RH}$ using an Ox-Tran Twin modular system (Mocon Inc., Minneapolis, MN). The coated side of the films was exposed to flowing oxygen gas, whereas the other side faced flowing nitrogen gas. Resulting OP values $\left(\mathrm{Q}_{\mathrm{tot}}\right)$ of multilayer films were received in terms of $\mathrm{cm}^{3}(\mathrm{STP}) \cdot \mathrm{m}^{-2} \cdot \mathrm{d}^{-1} \cdot \mathrm{bar}^{-1}$, where $\mathrm{STP}=$ standard temperature and pressure, and used for further calculation regarding permeability of the whey protein layer. The OP values (Q) of WPI-based coatings were converted to the thickness (d) of $100 \mu \mathrm{m}$ $\left(\mathrm{Q}_{100}\right)$ to allow direct comparison of different materials independently of the coating thickness as described 
previously. For every sample, a double determination was done. In case of a deviation $>10 \%$ between 2 OP values, a third determination was performed.

\section{Surface Energy Measurement}

The surface energy of WPI-based coatings was measured by a contact angle measuring system (G2; Krüss GmbH, Stephanskirchen/Rosenheim, Germany) using the sessile drop method as described by Schmid (2013). Double-distilled water, diiodomethane, and ethylene glycol were applied as testing liquids on the solid surface of a sample. The contact angle of each liquid was measured at 5 different positions. According to Young's equation, the surface energy can be calculated as follows:

$$
\sigma_{\mathrm{S}}=\gamma_{\mathrm{SL}}+\sigma_{\mathrm{L}} \cdot \cos \theta
$$

where $\sigma_{\mathrm{S}}$ and $\sigma_{\mathrm{L}}$ represent the surface tension of the solid and liquid, respectively, and $\gamma_{\mathrm{SL}}$ stands for the interfacial tension between solid and liquid (all in $\mathrm{mN} / \mathrm{m}$ ). The contact angle $\theta$ between the surface tension of the liquid and the interfacial tension between liquid and solid is given in angular degrees. Due to the Owens, Wendt, Rabel, and Kaelble method, the surface energy can be divided into polar and dispersive fractions, which were calculated additionally. Because the coatings were still partly soluble, the measurements had to be performed after a given time $(20 \mathrm{~s})$ and not at equilibrium. Hence, calculated values could not be considered as absolute surface energy values but are adequate for comparison of the samples among themselves.

\section{Statistical Analysis}

Results were analyzed using the statistical program Visual-XSel 12.0 Multivar (CRGRAPH, Munich, Germany). The Kolmogorov-Smirnov test procedure was applied for experiments having at least 4 determinations per sample to investigate if a normal distribution adequately described a data set. In all cases, the hypothesis of normality was validated at a level of significance of $5 \%$. Measurements with a smaller data set were not tested for normal distribution, but standard deviations were given accordingly. Extreme values of a sample were removed from a data set using the outlier tests of Grubbs or David, Hartley, and Pearson, respectively. The condition was that the other values were from the same population that was checked by the Kolmogorov-Smirnov test as mentioned above. A multiple $t$-test was performed to determine any significant difference among experimental treatments at $P \leq 0.05$.

\section{RESULTS AND DISCUSSION}

\section{TSM Measurement}

The results of TSM measurement are presented in Figure 1. The TSM in water decreased constantly as the proportion of denatured protein in the coatings increased. The only exception was the 25:75 (D:N) coating. Its solubility properties were equal to those of 0:100 (D:N) coatings, as no residues could be determined after $24 \mathrm{~h}$ of film-soaking treatment. These results confirm those of Guckian et al. (2006), where WPI-based films with ratios of 20:80 (D:N) were completely soluble in water, whereas those composed of at least $40 \%$ denatured WPI had a significantly lower TSM. During denaturation, the native 3-dimensional structure of the whey proteins is disrupted, which leads to unfolding and exposure of free thiol groups that were buried previously within the whey protein molecules (de Wit and Klarenbeek, 1984). Intermolecular linkages between the single molecules via thiol/thiol oxidations and disulfide-exchange reactions enable the formation of aggregates, which are responsible for the insolubility in water (Floris et al., 2008). Thus, coatings with higher ratios of denatured WPI might have higher proportions of reactive groups, which explain the decrease in solubility. Almost complete solubility of the 25:75 (D:N) coating could be explained by weak interactions between protein molecules due to the lower amount of free thiol groups (Guckian et al., 2006). It is conspicuous that, with exception of the 25:75 (D:N) coating, the TSM was almost equal to the sum of the proportions of glycerol and native WPI in a coating. This indicates that denatured WPI formed an insoluble network, whereas glycerol and native WPI were transferred (dissolved) completely into water.

No significant differences were found between coatings derived from 0:100 (D:N) WPI ratios and dried at different temperature-time profiles, as TSM was almost $100 \%$ in all cases. This indicates that high temperatures were not sufficient to induce denaturation at high levels. Whey protein isolate-based coatings with 100:0 (D:N) proportions did not significantly differ from each other either. The TSM was about $40 \%$, which is equal to the ratio of glycerol in the DM of the coating.

\section{Determination of the $D_{D e n}$ Using RP-HPLC}

Protein standards were used to identify and locate the peaks of individual whey protein fractions on the chromatogram of WPI. The elution times of BSA, $\alpha$-LA, $\beta$-LG B, and $\beta$-LG A were $6.68,7.25,11.35$, and $11.91 \mathrm{~min}$, respectively (Figure 2). The elution order is in agreement with the work of various other researchers 


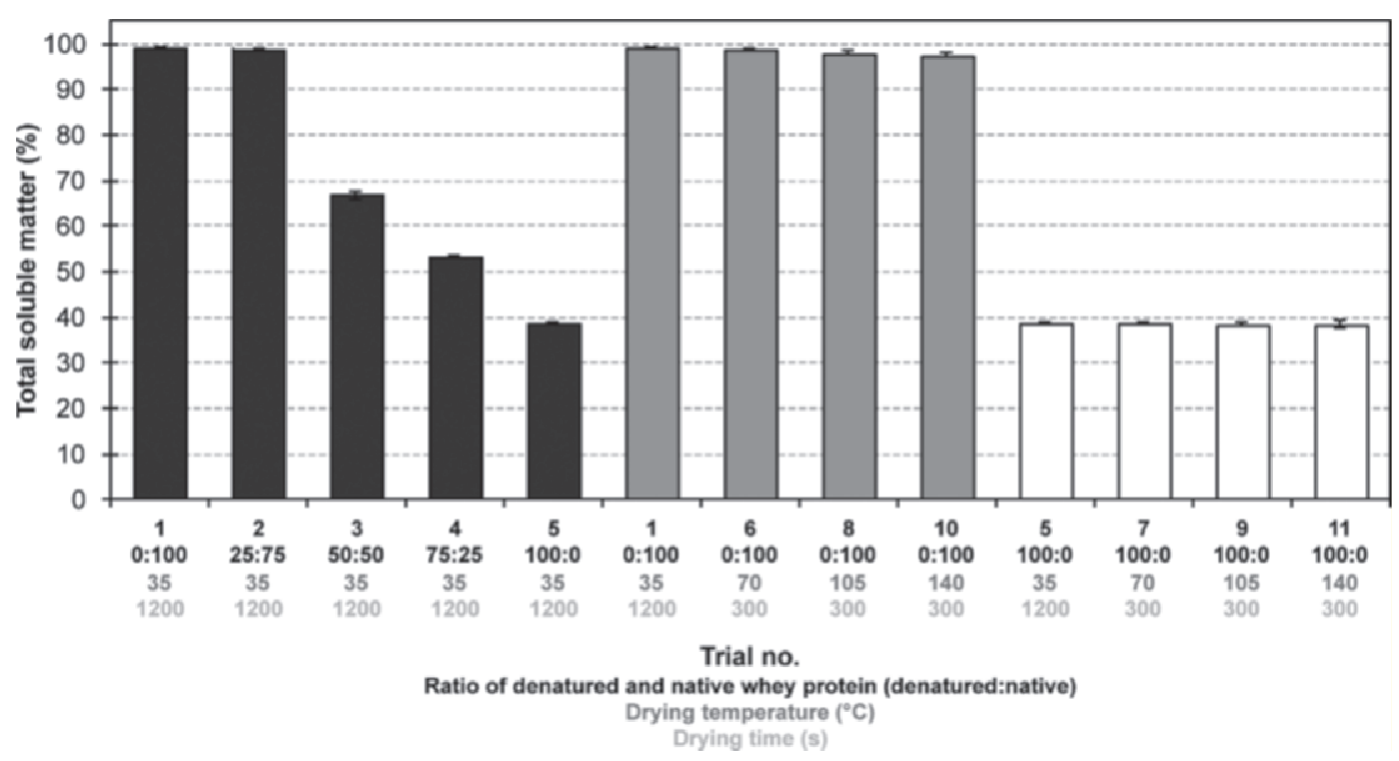

Figure 1. Total soluble matter in water of whey protein isolate (WPI)-based coatings produced from various ratios of heat-denatured (D) and native $(\mathrm{N})$ whey protein solutions and dried at different temperature-time profiles $[0: 100$ to 100:0 (D:N) at 35 $\mathrm{C}$ (black), 0:100 (D:N) at 35 to $140^{\circ} \mathrm{C}$ (gray), and 100:0 (D:N) at 35 to $140^{\circ} \mathrm{C}$ (white)] after a film-soaking time of $24 \mathrm{~h}$ at $23^{\circ} \mathrm{C}$. Error bars represent SD.

(Parris and Baginski, 1991; Ferreira and Caçote, 2003; Haque et al., 2013a,b). Values between specimens differed within an average deviation of less than $2 \%$. This emphasizes the suitability of RP-HPLC as an adequate method for quantifying the degree of whey protein denaturation.

Figure 3 illustrates the $\mathrm{D}_{\text {Den }}$ of WPI-based coatings. These differ in their D:N ratio as well as in the applied temperature-time profile during drying. Solutions with equal D:N ratios were used for comparison. For all solutions as well as solubilized coatings, the determined $\mathrm{D}_{\text {Den }}$ was almost equal to the theoretical one set during formulation preparation. This indicates that the native share of WPI was completely dissolved in water, which correlates with the results of TSM measurement. Furthermore, convective drying at $35^{\circ} \mathrm{C}$ for $1,200 \mathrm{~s}$ and subsequent solubilization did not increase the $D_{\text {Den }}$ to any further extent.

Coatings with 0:100 (D:N) ratios and dried at various temperatures were not significantly different from each other. At $140^{\circ} \mathrm{C}$, a denaturation of $2.5 \%$ was determined, which indicates only partial denaturation during convective drying. All coatings made of 100:0 (D:N) formulations showed equal amounts of denatured whey protein, which was about $98.5 \%$.

Whey protein isolate is a heterogeneous protein containing various whey protein fractions such as BSA, $\alpha-\mathrm{LA}$, and $\beta$-LG A and B, which have different sensitivities to heat treatment. The $\mathrm{D}_{\text {Den }}$ of those proteins are illustrated in Figure 4. Both genetic variants of $\beta$-LG showed similar $D_{\text {Den }}$ with no significant differ- ences observed. This is in agreement with previous studies (Considine et al., 2007; Haque et al., 2013a) and is consistent for all coatings. In coatings made of 100:0 (D:N) formulations, the degree of $\beta-\mathrm{LG}$ denaturation was $100 \%$. Temperatures above $65^{\circ} \mathrm{C}$ denature $\beta$-LG irreversibly due to the disruption of its tertiary structure. The exposure of the previously buried free thiol groups initiates aggregation via thiol-disulfide exchange reactions (de Wit, 2009). As 100:0 (D:N) solutions were produced by heating native WPI formulations for 30 min at $90^{\circ} \mathrm{C}$, this temperature-time profile was sufficient to denature the $\beta-\mathrm{LG}$ fraction completely. This was confirmed because no $\beta-\mathrm{LG}$ denaturation was found in solubilized 100:0 (D:N) coatings, whether they were dried at temperatures of $35,70,105$, or $140^{\circ} \mathrm{C}$. Because the last 2 temperatures are significantly higher than the minimum denaturation temperature of $65^{\circ} \mathrm{C}$, this suggests that temperatures of at least $65^{\circ} \mathrm{C}$ were not reached during the convective drying process or that the drying time of 5 min was too short to initiate unfolding in the case of the 0:100 (D:N) coatings.

The first hypothesis of too low temperatures to initiate denaturation is supported by the effect of evaporative cooling as was observed in the work of Haque et al. (2013b): the temperature of coating remained close to the wet bulb temperature as long as enough water was available for evaporation. Only if less water became available, the coating temperature rose toward the air temperature of the coating unit. Another explanation could be the effect of dehydration during the drying process. Haque et al. (2013a) reported that when a 


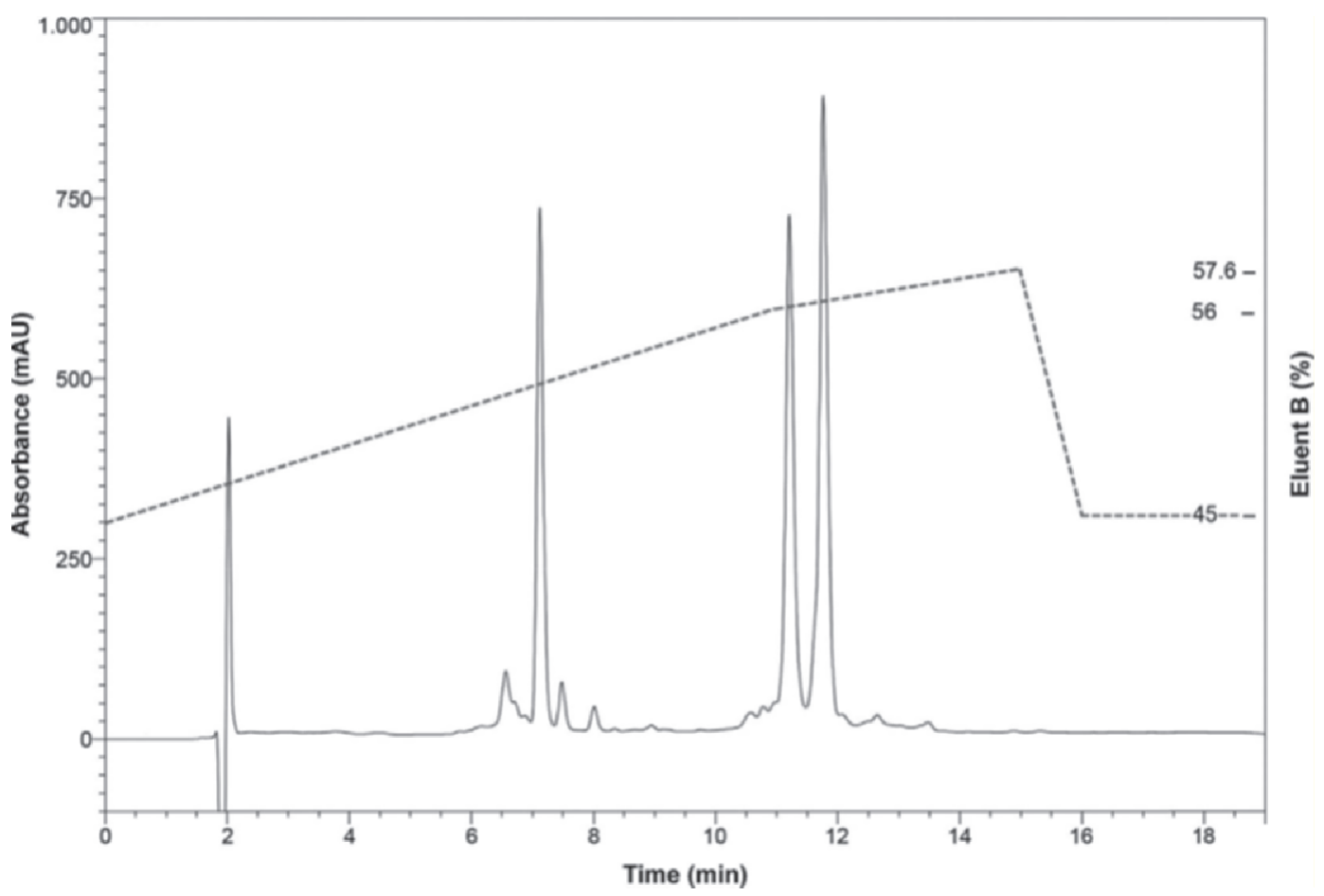

Figure 2. Chromatogram of a native, untreated whey protein isolate (WPI) sample with a protein concentration of $0.1 \%$ (wt/wt) and an injection volume of $40 \mu \mathrm{L}$. Peaks identified with whey protein standards. The broken line shows the elution gradient and the right y-axis indicates the share of eluent $\mathrm{B}$ at a certain time. $\mathrm{mAU}=$ milliabsorbance units.

WPI-based solution of $10 \%$ (wt/wt) was concentrated to $64 \%$ through convective drying, the extent of denaturation was maintained constant. Because the pres- ence of water is essential for whey protein denaturation to occur, higher DM concentration provides protections against denaturation due to lower molecular mobility

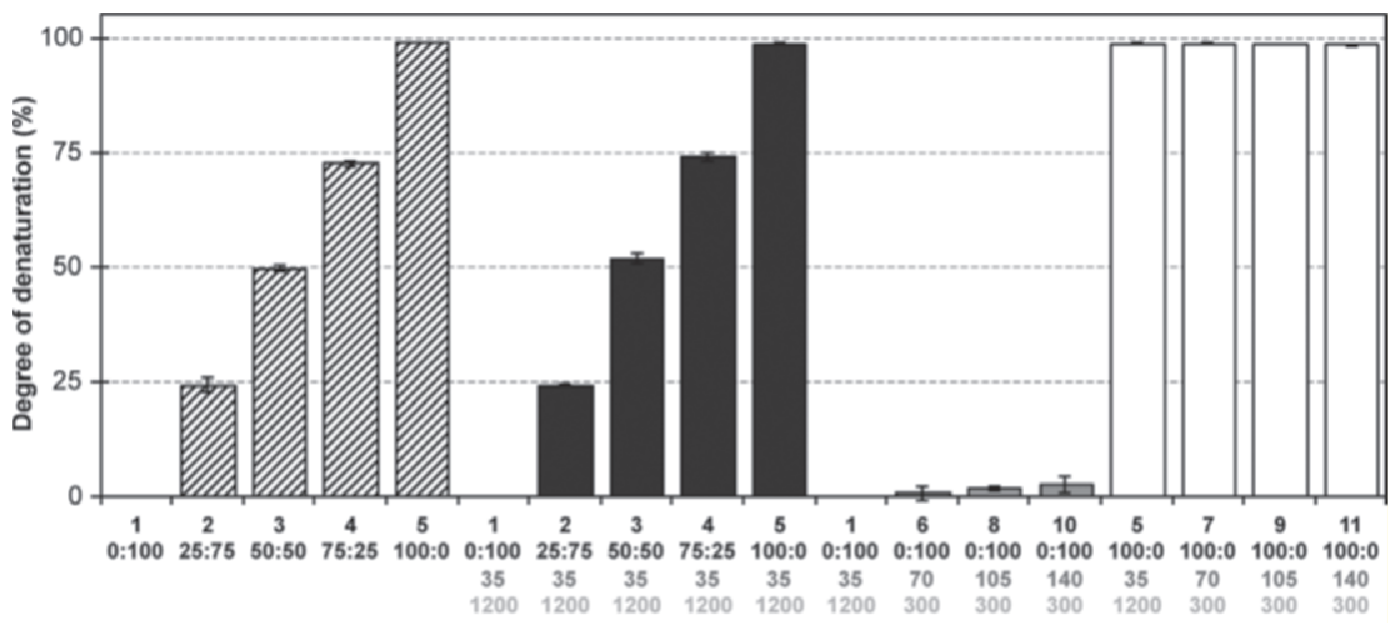

Trial no.

Ratio of denatured and native whey protein (denatured:native)

Drying temperature $\left({ }^{\circ} \mathrm{C}\right)$ Drying time (s)

Figure 3. Degrees of denaturation of whey protein isolate (WPI)-based solutions (striped bars) and WPI-based coatings immersed in water for $24 \mathrm{~h}$ at $23^{\circ} \mathrm{C}$, produced from various ratios of heat-denatured (D) and native (N) whey protein solutions and dried at different temperaturetime profiles [0:100 to 100:0 (D:N) at $35^{\circ} \mathrm{C}$ (black), 0:100 (D:N) at 35 to $140^{\circ} \mathrm{C}$ (gray), and 100:0 (D:N) at 35 to $140^{\circ} \mathrm{C}$ (white)]. Error bars represent SD. 


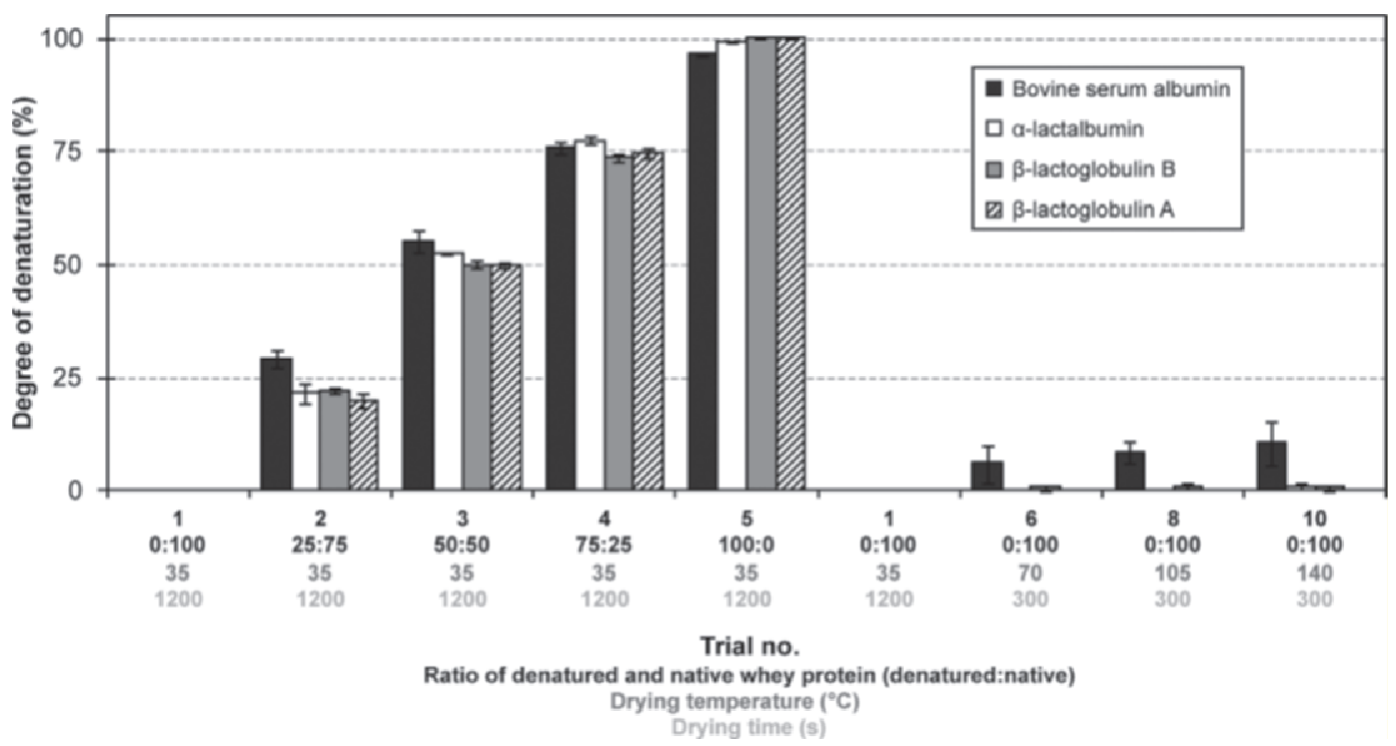

Figure 4. Degrees of denaturation of whey protein isolate (WPI) fractions determined in WPI-based coatings produced from various ratios of heat-denatured (D) and native (N) whey protein solutions and dried at different temperature-time profiles after $24 \mathrm{~h}$ of immersion in water at $23^{\circ} \mathrm{C}$. Error bars represent SD.

(Haque et al., 2013b). Similar results were observed for soy protein isolate (Galani and Owusu Apenten, 1999) solutions: whereas the denaturation temperature at $94 \%$ (wt/wt) water content was maintained below $100^{\circ} \mathrm{C}$, it increased to $184^{\circ} \mathrm{C}$ when the water content decreased to $11 \%$ (wt/wt; Kitabatake and Doi, 1991).

The second hypothesis is supported by the fact that next to temperature, time is another parameter that influences the $\mathrm{D}_{\mathrm{Den}}$. Even if $\beta$-LG experiences an unfolding temperature of $65^{\circ} \mathrm{C}$, a minimum time of $5 \mathrm{~min}$ is necessary for irreversible denaturation (de Wit, 2009; Haque et al., 2013b). It might be applicable to the results of this work that the heating time of the coating was too long, whereas the residual time for protein unfolding was too short during convective drying.

Figure 4 shows that the $\mathrm{D}_{\text {Den }}$ of $\alpha-\mathrm{LA}$ is in the same range as that of $\beta-\mathrm{LG}$. Although no trend was observed for coatings made of different D:N proportions, all fully denatured coatings had $\mathrm{D}_{\text {Den }}$ of about $98 \%$. The remaining nativity of $2 \%$ derived only from the $\alpha$-LA fraction of WPI. Higher stability of $\alpha$-LA compared with other whey protein fractions was constantly reported in former studies (Parris and Baginski, 1991; Ferreira et al., 2001; Oldfield et al., 2005; Anandharamakrishnan et al., 2008; Haque et al., 2013a). The $\alpha$-LA fraction of WPI does not contain a free thiol group. As a consequence, it is less affected by thermal stresses as well as thiol-disulfide interactions (Calvo et al., 1993). As selfaggregation of unfolded $\alpha$-LA molecules is not possible, whey protein fractions that contain free thiol groups, such as $\beta$-LG and BSA, are necessary for the formation of agglomerates (Calvo et al., 1993). No denaturation of $\alpha$-LA was found after the drying of 0:100 (D:N) coatings at temperatures up to $140^{\circ} \mathrm{C}$. Evaporative cooling and a long heating time might also be explanations for this whey protein.

Contrary to the other WPI fractions, BSA showed significantly higher $\mathrm{D}_{\text {Den }}$ in all coatings. It was the only protein that denatured in native coatings dried at temperatures of 70,105 , and $140^{\circ} \mathrm{C}$, leading to $10.2 \%$ of BSA denaturation on top. Hence, only the denaturation of BSA might be responsible for detectable overall denaturation. Similar to $\beta$-LG, BSA contains 1 free thiol group. However, it was reported to be one of the most unstable whey protein fractions (Parris and Baginski, 1991; Oldfield et al., 2005). Under heat treatment, the rate of nativity loss of the 3 major whey proteins was reported to be $\mathrm{BSA}>\beta-\mathrm{LG} \approx \alpha-\mathrm{LA}$ (Considine et al., 2007). This observation is consistent with the results obtained in the current study. As BSA unfolds at lower temperatures than $\beta$-LG $\left(52^{\circ} \mathrm{C}\right.$ instead of $65^{\circ} \mathrm{C}$; Gezimati et al., 1996), a higher $\mathrm{D}_{\text {Den }}$ seems more likely.

To our knowledge, 2 other research papers about the relationship between the degree of whey protein denaturation and the temperature-time profile applied during convective drying exist so far (Haque et al., $2013 \mathrm{a}, \mathrm{b})$. Single droplets $(\mathrm{d}=0.2 \mathrm{~mm})$ of $10 \%(\mathrm{wt} / \mathrm{wt})$ native WPI solution were dried in a compartment dryer at various temperatures. $\mathrm{A} \mathrm{D}_{\mathrm{Den}}$ of $50 \%$ was reported after drying for $5 \mathrm{~min}$ at $80^{\circ} \mathrm{C}$. In contrast, the results of the current work showed a $\mathrm{D}_{\text {Den }}$ of $2.5 \%$ after $5 \mathrm{~min}$ at $140^{\circ} \mathrm{C}$. In the other studies, it was reported that next 


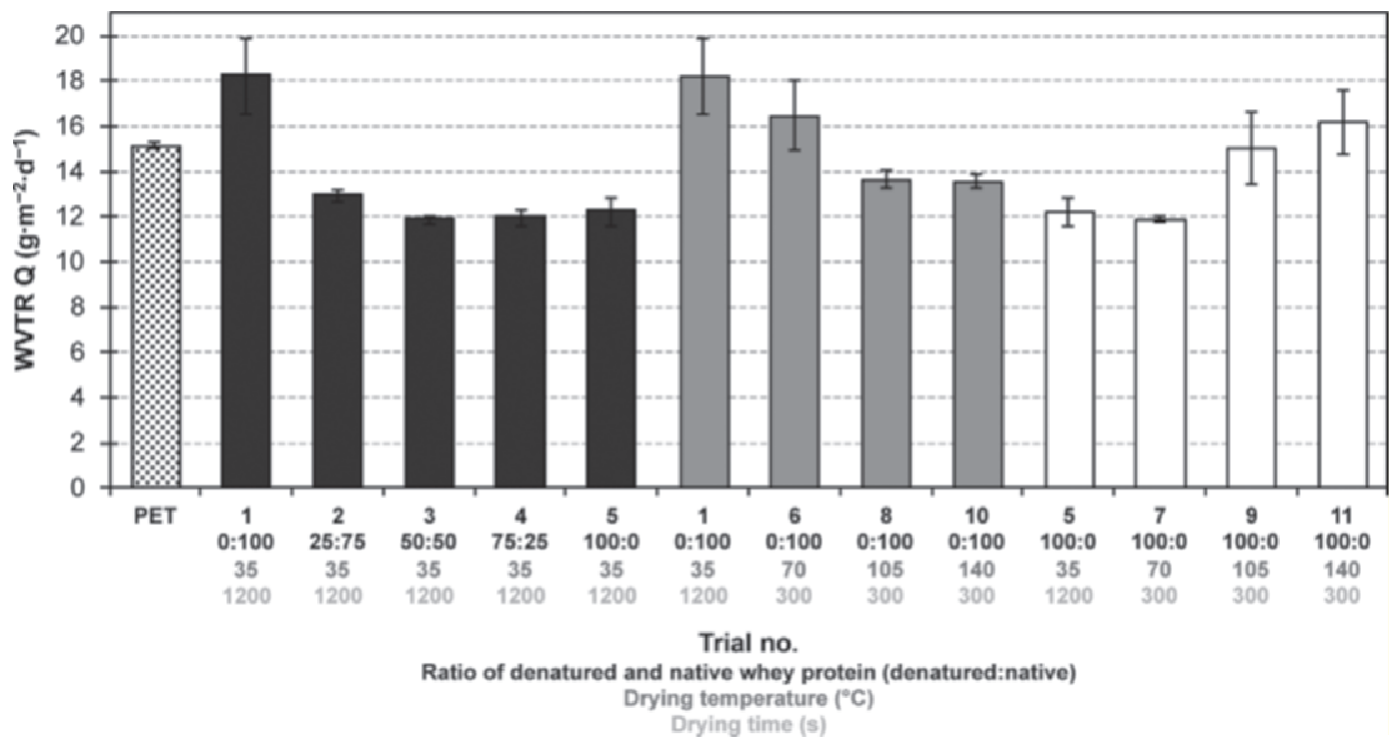

Figure 5. Water vapor transmission rate values (WVTR Q) of whey protein isolate (WPI)-based coatings produced from various ratios of heat-denatured (D) and native $(\mathrm{N})$ whey protein solutions and dried at different temperature-time profiles [0:100 to 100:0 (D:N) at 35 ${ }^{\circ} \mathrm{C}$ (black), 0:100 (D:N) at 35 to $140^{\circ} \mathrm{C}$ (gray), and 100:0 (D:N) at 35 to $140^{\circ} \mathrm{C}$ (white)], determined at $23^{\circ} \mathrm{C}$ and $85 \% \rightarrow 0 \%$ relative humidity, with $4.34 \mu \mathrm{m}$ average coating thickness. Error bars represent SD. PET $=$ polyethylene terephthalate.

to thermal stress, stress associated with dehydration through water evaporation plays a major role for the $\mathrm{D}_{\text {Den }}$, as interfacial stress irreversibly denatures whey proteins at the air-solution interface (Maa et al., 1998). Thus, up to temperatures of $65^{\circ} \mathrm{C}$, interfacial stress dominates the $\mathrm{D}_{\text {Den }}$, whereas above $65^{\circ} \mathrm{C}$, heating stress is more dominant (Haque et al., 2013a). The drying rate is direct proportional to the surface area of the drying goods (Haque et al., 2013b). If temperatures $>65^{\circ} \mathrm{C}$ were not reached in the current study due to evaporative cooling, interfacial stress might have been responsible for the partial whey protein unfolding of the 0:100 (D:N) coating dried at $140^{\circ} \mathrm{C}$ as determined via RP-HPLC.

Furthermore, droplets are spherical and subject to thermal stress from all sides. A thin coating is plate shaped and mainly stressed from only 1 dimension. Because the surface of a droplet is 4 times larger than the surface of a circle with the same diameter, the thermal stress is considerably less.

\section{WVTR Measurement}

It was not possible to calculate the WVTR $\mathrm{Q}_{100}$ value of the 0:100 (D:N) coating dried at $35^{\circ} \mathrm{C}$ because its transmission rate was higher than the one of pure substrate (see Equation 5). As this coating denotes the initial condition, the $\mathrm{Q}_{\text {tot }}$ values of PET-WPI laminates are used for interpretation. Figure 5 illustrates the WVTR of dual-layer films at $23^{\circ} \mathrm{C}$ and $85 \% \rightarrow 0 \% \mathrm{RH}$, each consisting of a PET substrate and a WPI-based coating produced from different D:N ratios and dried at various temperature-time profiles. For comparison, values of pure PET are given as well.

It can be seen that the WVTR decreased significantly by almost $30 \%$ when the share of denatured WPI increased from 0 to $25 \%$. Further increase of denatured WPI decreased the WVTR only by a little extent. No differences were observed between coatings with a 50:50, 75:25, and 100:0 (D:N) ratio. These observations are in correlation with the research of Guckian et al. (2006), where no difference regarding the permeability of water vapor was found between WPI-based films with shares of denatured protein between 40 and 100\%. However, films composed of $20 \%$ denatured whey protein were significantly more permeable. In general, denatured WPI films provide higher barrier properties against water vapor than native ones, although differences are sometimes found to be marginal (McHugh et al., 1994; Pérez-Gago et al., 1999). The reason commonly given is that heat-denatured whey proteins are cross-linked by intermolecular disulfide bonds, whereas native whey proteins are supposed to be less tightly bound as they provide weaker protein-protein interactions (PérezGago et al., 1999; Perez-Gago and Krochta, 2001; Guckian et al., 2006). Therefore, it could be assumed that a continuous increase of the share of denatured WPI should result in a continuous decrease of the WVTR. However, a comparison between the permeability of WPI and $\beta$-LG films suggests that the whey protein 
structure does not influence the barrier properties (Maté and Krochta, 1996). The results of the current work indicate that the WVTR decreases up to a share of $25 \%$ denatured WPI, whereas a further increase in the denatured proportion has no further effect. This observation could be explained by the permeability behavior of water vapor through whey protein-based films. The water vapor permeability depends on the water vapor permeation coefficient as intrinsic material property. As the water vapor permeation coefficient is the product of the water vapor solubility coefficient and the water vapor diffusion coefficient, both coefficients directly affect the WVTR of whey protein-coated films. As quite recently published by Schmid et al. (2014), it is evident that in the case of whey protein films, an additional cross-linking leads to decreased WVTR due to the decrease of the effective diffusion coefficient, whereas the solubility coefficient stays constant. Therefore, the hypothesis can be proposed that the heat-denatured proteins do cross-link by intermolecular disulfide bonds, as postulated by Guckian et al. (2006), (Pérez-Gago et al. (1999), and Perez-Gago and Krochta (2001), but already a degree of denaturation of $25 \%$ and the resulting cross-linking is sufficient to reduce the diffusion coefficient to its minimum. In the case of whey protein-coated substrates as in the current study, is it not possible to apply the same method as Crank (1975) for determining the diffusion coefficient, as cast films are needed for the sorption experiments. Also, the commonly used time-lag method to determine the diffusion coefficient cannot be applied in this work, as the necessary dehumidification of the films for applying this method led to brittle films which could not be characterized. Thus, it was not directly possible to prove or falsify the hypotheses. Nevertheless, the abovementioned indications emphasize that the given explanation could be applied to the observations in the current study.

The WVTR of coatings composed of 0:100 (D:N) ratios and dried at different temperatures decreased significantly with an increase in drying temperature from 35 to $105^{\circ} \mathrm{C}$, whereas no difference existed between coatings dried at 105 and $140^{\circ} \mathrm{C}$. These results indicate that whey proteins in the coating were at least partially unfolded during convective drying, which confirms the results of the RP-HPLC analysis.

In contrast, WVTR values of coatings made of 100:0 (D:N) solutions increased after drying at 105 and $140^{\circ} \mathrm{C}$, respectively. Researchers reported that without adequate amounts of plasticizer, whey protein-based films may crack (McHugh et al., 1994; Maté and Krochta, 1996). Because water acts as a plasticizer, coatings with lower EMC should tend to be more brittle (Hong and Krochta, 2003). This might explain the higher transmission rates of coatings dried at 105 and $140^{\circ} \mathrm{C}$, which had a lower EMC than coatings dried at lower temperatures.

\section{OP Measurement}

Figure 6 displays the $\mathrm{OP} \mathrm{Q}_{100}$ values of WPI-based coatings at $23^{\circ} \mathrm{C}$ and $50 \% \mathrm{RH}$. Values for the PET substrate are given for comparison. No significant differences existed between coatings composed of 0 to $50 \%$ denatured WPI. These results suggest that the whey protein structure has no significant effect on OP, as confirmed in several publications (Maté and Krochta, 1996; Pérez-Gago et al., 1999; Schmid, 2013; Schmid et al., 2013b). However, differences were always significant between 0:100 and 100:0 and 75:0 (D:N) coatings dried at equal temperatures. This observation was described by Perez-Gago and Krochta (2001), who determined differences between native and denatured WPI-based films, although values were of the same order of magnitude. In the current work, 100:0 (D:N) coatings provided approximately $33 \%$ lower OP compared with native coatings. This could be due to a more linear structure of unfolded whey proteins, which might lead to higher cohesive energy density as well as higher cross-linking degree and lower free volume among polymer chains, as suggested by Perez-Gago and Krochta (2001). More evidence for this explanation is the increasing dispersive part of the surface energy when the degree of denaturation increased, as explained in the next section. Thus, the oxygen permeability decreases when the degree of denaturation is equal to or higher than $75 \%$ due to a higher potential to form covalent cross-links in the protein network. This is also in compliance with the results from Schmid et al. (2014), where the oxygen permeability decreased when additional cross-linking was induced.

Comparing coatings with 0:100 (D:N) ratios and dried at different temperatures, differences existed between those dried at 35 and $105^{\circ} \mathrm{C}$ and those dried at 35 and $140^{\circ} \mathrm{C}$, respectively. All other coatings did not differ from each other significantly. The OP for coatings dried at $140^{\circ} \mathrm{C}$ was higher, which is in contrast to the results of WVTR measurement. No significant differences were obtained for coatings derived from 100:0 (D:N) solutions and dried at various temperatures.

\section{Surface Energy Measurement}

The results of surface energy measurement can be reviewed from Figure 7. It shows total surface energy as well as dispersive and polar fractions.

Total surface energy decreased by $20 \%$ when D:N ratio changed from 0:100 to 25:75. However, further 


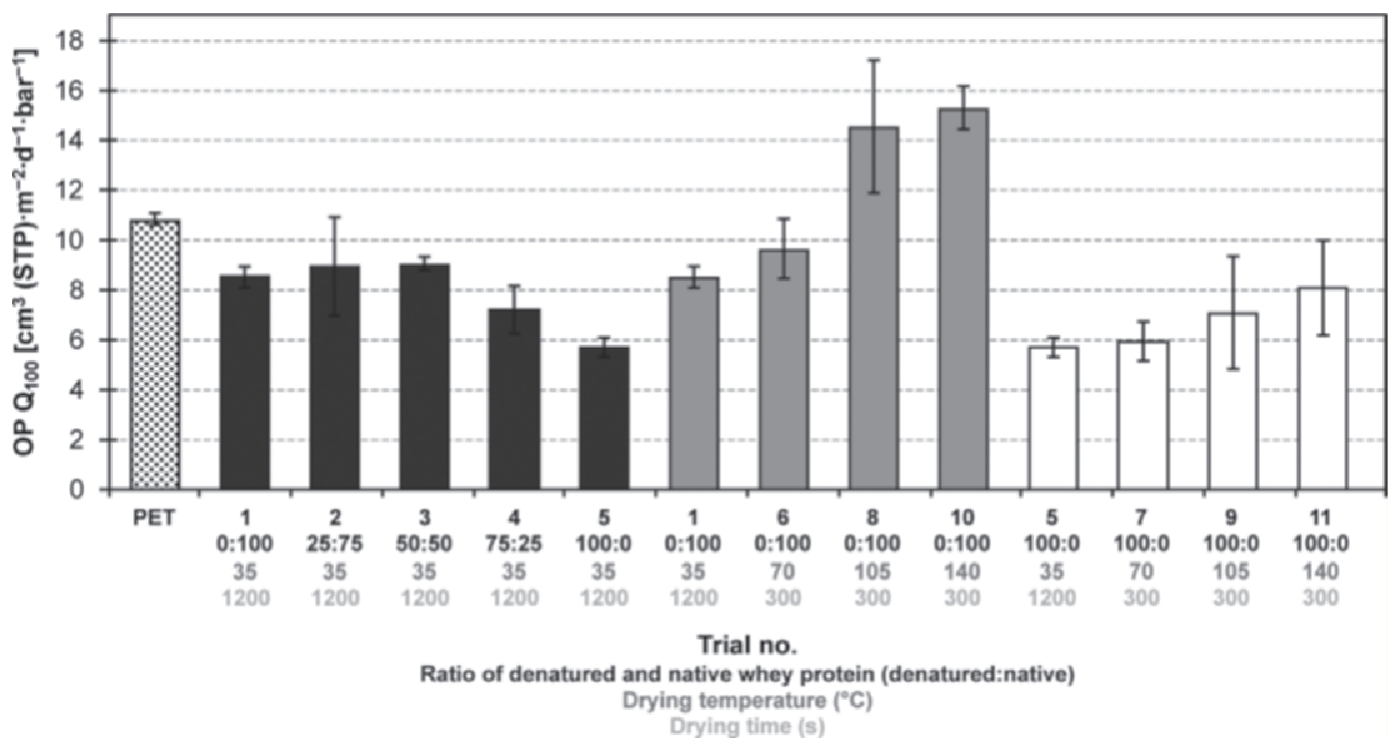

Figure 6. Oxygen permeability (OP) of whey protein isolate (WPI)-based coatings produced from various ratios of heat-denatured (D) and native $(\mathrm{N})$ whey protein solutions and dried at different temperature-time profiles [(0:100 to 100:0 (D:N) at $35^{\circ} \mathrm{C}$ (black), 0:100 (D:N) at 35 to $140^{\circ} \mathrm{C}$ (gray), and 100:0 (D:N) at 35 to $140^{\circ} \mathrm{C}$ (white)], determined at $23^{\circ} \mathrm{C}$ and $50 \%$ relative humidity. Error bars represent SD. $\mathrm{Q}_{100}=$ film thickness of $100 \mu \mathrm{m} ; \mathrm{STP}=$ standard temperature and pressure; PET $=$ polyethylene terephthalate.

increase of denatured WPI up to a 100:0 (D:N) ratio did not decrease the total surface energy any further. Conformational changes of the tertiary structure during denaturation result in the unfolding of whey protein molecules. This process is accompanied by the exposure of hydrophobic amino acid residues, such as tryptophan, at the protein surface (de Wit, 2009). Therefore, total surface energy decreases if a share of native WPI is replaced by fully denatured WPI. The polar part of the surface energy decreased significantly with an increasing ratio of denatured WPI. This is consistent with the results of total surface energy, as the biggest difference was found between 0:100 and 25:75 (D:N) ratios. The dispersive part of surface energy increased significantly

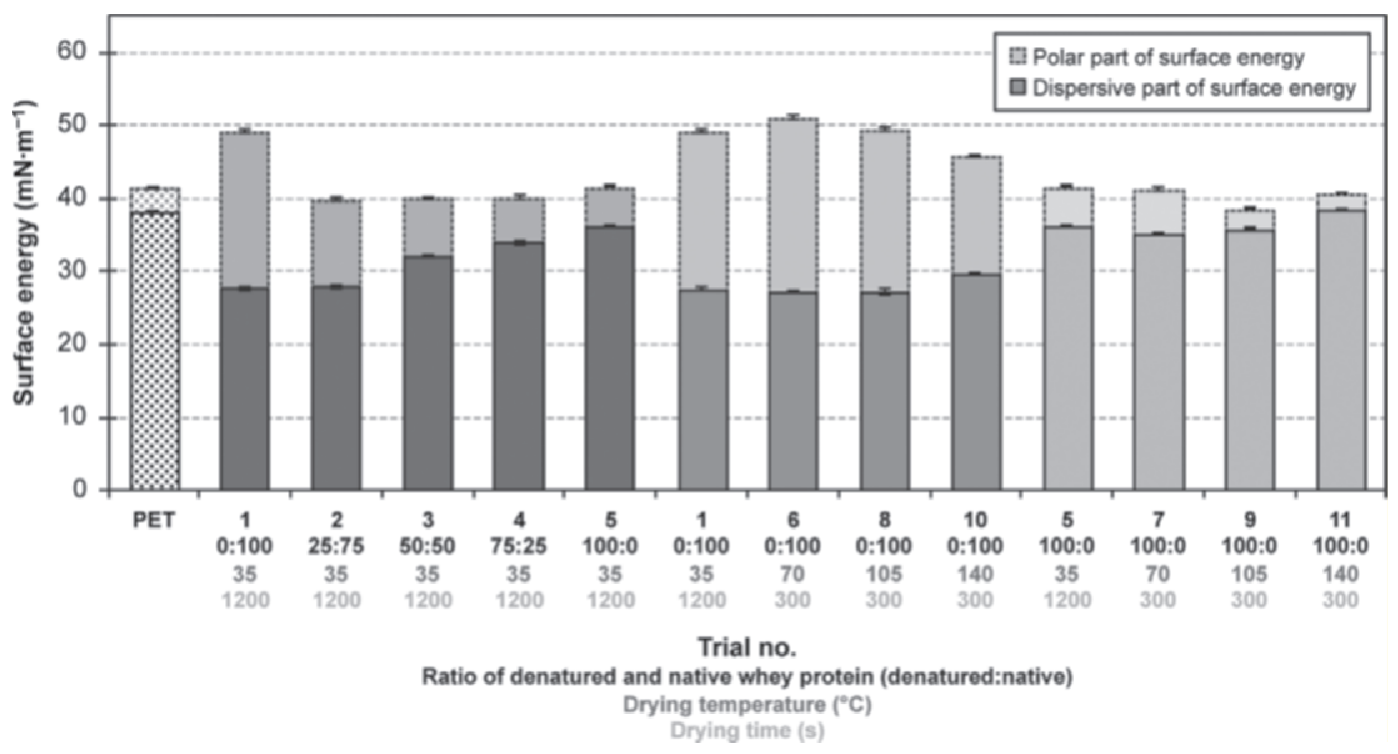

Figure 7. Surface energy of whey protein isolate (WPI)-based coatings produced from various ratios of heat-denatured (D) and native (N) whey protein solutions and dried at different temperature-time profiles [(0:100 to 100:0 (D:N) at $35^{\circ} \mathrm{C}$ (dark gray), 0:100 (D:N) at 35 to $140^{\circ} \mathrm{C}$ (mid gray), and 100:0 (D:N) at 35 to $140^{\circ} \mathrm{C}$ (light gray)], determined at $23^{\circ} \mathrm{C}$ and $50 \%$ relative humidity. Error bars represent $\mathrm{SD}$. $\mathrm{PET}=$ polyethylene terephthalate. 
in correlation with the share of denatured WPI. These observations can be explained by van der Waals forces, which occur in dispersive materials (Drummond and Chan, 1997). Subsequently to the unfolding of whey proteins during denaturation, they aggregate. Increasing the amount of denatured whey protein leads to enhanced aggregation due to an increased number of free thiol groups (Guckian et al., 2006). Thus, the molecular weight should also increase. As the molecular weight is roughly proportional to the number of electrons in the outermost shell of a molecule, the van der Waals forces along the polymer chains are increased as well and lead to a higher dispersive part of surface energy (Pauling, 1988). This is consistent with results from Schmid (2013), where the influence of molecular weight in WPI-based cast films on the polar and dispersive part of the surface energy was studied.

No differences in total surface energy were observed between coatings with $0: 100(\mathrm{D}: \mathrm{N})$ ratios that were dried at 35,70 , and $105^{\circ} \mathrm{C}$. However, coatings dried at $140^{\circ} \mathrm{C}$ showed a significant decrease in total surface energy compared with the other 0:100 (D:N) coatings. This indicates that whey proteins in those coatings were at least partially unfolded during convective drying, confirming the results of the RP-HPLC analysis. This suggestion is supported by the results for polar and dispersive surface energy fractions. The polar part decreased by approximately $25 \%$, whereas the dispersive part increased by about 9\% for the 0:100 (D:N) coating dried at $140^{\circ} \mathrm{C}$.

No significant differences in total surface energy were found between 100:0 (D:N) coatings dried at different temperature-time profiles. Furthermore, coatings had equal polar fractions if dried at 35 or $70^{\circ} \mathrm{C}$ but increased polar fractions at 105 and $140^{\circ} \mathrm{C}$. This might be the result of a decreased EMC, which was observed at higher drying temperatures. A lower EMC might result in a lower number of polar hydrogen bonds due to less embedded water molecules. With a lower number of hydrogen bonds, the polar part of the surface energy should be decreased, as was observed. No differences in the dispersive part of surface energy were found between 100:0 (D:N) coatings dried at various temperatures.

\section{CONCLUSIONS}

This study highlights the necessity of whey protein denaturation to receive WPI-based coatings with improved technological-functional properties compared with fully native ones. Fully denatured whey protein formulations $\left(\mathrm{D}_{\text {Den }}\right.$ of $\left.100 \%\right)$ decreases the WVTR by approximately $35 \%$, OP by $33 \%$, and surface energy by approximately $20 \%$ compared with fully native WPI formulations. Higher proportions of denatured WPI do not lead to further improvement of material properties. This observation offers cost-saving potential: up to $75 \%$ of predenatured WPI formulation may be replaced by a fully native one without altering the technologicalfunctional properties of the resulting coatings. Native whey proteins are not exposed to energy-intensive heat treatment. Additionally, native WPI formulations can be produced with higher DM content without becoming too viscous to spread on the substrate during the coating process. This leads to smaller quantities of moisture that have to be removed during drying. Furthermore, convective drying with a temperature-time profile of $140^{\circ} \mathrm{C} / 5 \mathrm{~min}$ is not adequate to denature native WPIbased formulations to more than $2.5 \%$ under the given experimental design. Nevertheless, denaturation in this range can improve technological-functional properties, although differences compared with fully native WPIbased coatings are not always found to be significant. To gain more information on the effect of the degree of denaturation on the techno-functional properties of WPI-based films it would be worth studying if denatured proteins aggregate as a separate network from native ones after forming films and how micro/nanoscopic structures are correlated with film properties.

\section{ACKNOWLEDGMENTS}

The authors acknowledge the support from all involved colleagues at Fraunhofer-Institute for Process Engineering and Packaging IVV (Freising, Germany).

\section{REFERENCES}

Anandharamakrishnan, C., C. D. Rielly, and A. G. F. Stapley. 2008. Loss of solubility of $\alpha$-lactalbumin and $\beta$-lactoglobulin during the spray drying of whey proteins. Lebensm. Wiss. Technol. 41:270277. http://dx.doi.org/10.1016/j.lwt.2007.03.004.

Bugnicourt, E., M. Schmid, O. M. Nerney, J. Wildner, L. Smykala, A. Lazzeri, and P. Cinelli. 2013. Processing and validation of wheyprotein-coated Films and laminates at semi-industrial scale as novel recyclable food packaging materials with excellent barrier properties. Adv. Materials Sci. Eng. 2013:496207. http://dx.doi. org $/ 10.1155 / 2013 / 496207$.

Calvo, M. M., J. Leaver, and J. M. Banks. 1993. Influence of other whey proteins on the heat-induced aggregation of $\alpha$-lactalbumin. Int. Dairy J. 3:719-727. http://dx.doi.org/10.1016/09586946(93)90085-E.

Considine, T., H. A. Patel, S. G. Anema, H. Singh, and L. K. Creamer. 2007. Interactions of milk proteins during heat and high hydrostatic pressure treatments - A review. Innov. Food Sci. Emerg. Technol. 8:1-23. http://dx.doi.org/10.1016/j.ifset.2006.08.003.

Crank, J. 1975. The Mathematics of Diffusion. 2nd ed. Clarendon Press, Oxford, UK.

de Wit, J. N. 2001. Lecturer's Handbook on Whey and Whey Products. European Whey Products Association, Brussels, Belgium.

de Wit, J. N. 2009. Thermal behaviour of bovine $\beta$-lactoglobulin at temperatures up to $150{ }^{\circ} \mathrm{C}$. A review. Trends Food Sci. Technol. 20:27-34. http://dx.doi.org/10.1016/j.tifs.2008.09.012.

de Wit, J. N., and G. Klarenbeek. 1984. Effects of various heat treatments on structure and solubility of whey proteins. J. 
Dairy Sci. 67:2701-2710. http://dx.doi.org/10.3168/jds.S00220302(84)81628-8.

DIN (Deutsches Institut für Normung). 1998. Testing of plasticsDetermination of gas transmission rate - Part 3: Oxygen-specific carrier gas method for testing of plastic films and plastics mouldings. DIN 53380-3. Deutsches Institut für Normung e.V., Berlin, Germany.

DIN (Deutsches Institut für Normung). 2001. Testing of plastics and elastomer films, paper, board and other sheet materials - Determination of water vapour transmission-Part 1: Gravimetric method. DIN 53122-1. Deutsches Institut für Normung e.V., Berlin, Germany.

Drummond, C. J., and D. Y. C. Chan. 1997. van der Waals interaction, surface free energies, and contact angles: Dispersive polymers and liquids. Langmuir 13:3890-3895. http://dx.doi.org/10.1021/ la962131c.

Ferreira, I. M. P. L. V. O., and H. Caçote. 2003. Detection and quantification of bovine, ovine and caprine milk percentages in protected denomination of origin cheeses by reversed-phase high-performance liquid chromatography of beta-lactoglobulins. J. Chromatogr. A 1015:111-118. http://dx.doi.org/10.1016/S0021-9673(03)01261-5.

Ferreira, I. M. P. L. V. O., E. Mendes, and M. A. Ferreira. 2001. HPLC/UV analysis of proteins in dairy products using a hydrophobic interaction chromatographic column. Anal. Sci. 17:499 501. http://dx.doi.org/10.2116/analsci.17.499.

Floris, R., I. Bodnar, F. Weinbreck, and A. C. Alting. 2008. Dynamic rearrangement of disulfide bridges influences solubility of whey protein coatings. Int. Dairy J. 18:566-573. http://dx.doi. org/10.1016/j.idairyj.2007.10.013

Galani, D., and R. K. Owusu Apenten. 1999. Heat-induced denaturation and aggregation of $\beta$-lactoglobulin: Kinetics of formation of hydrophobic and disulphide-linked aggregates. Int. J. Food Sci. Technol. 34:467-476. http://dx.doi.org/10.1046/j.13652621.1999.00314.x.

Gezimati, J., H. Singh, and L. K. Creamer. 1996. Heat-induced interactions and gelation of mixtures of bovine $\beta$-lactoglobulin and serum albumin. J. Agric. Food Chem. 44:804-810. http://dx.doi. org/10.1021/jf950445k.

Ghanbarzadeh, B., and H. Almasi. 2013. Biodegradable polymers. Pages 141-186 in Biodegradation-Life of Science. R. Chamy and F. Rosenkranz, ed. InTech, Rijeka, Croatia.

Guckian, S., C. Dwyer, M. O'Sullivan, E. D. O'Riordan, and F. J. Monahan. 2006. Properties of and mechanisms of protein interactions in films formed from different proportions of heated and unheated whey protein solutions. Eur. Food Res. Technol. 223:91-95. http://dx.doi.org/10.1007/s00217-005-0140-9.

Haque, M. A., P. Aldred, J. Chen, C. J. Barrow, and B. Adhikari. 2013a. Comparative study of denaturation of whey protein isolate (WPI) in convective air drying and isothermal heat treatment processes. Food Chem. 141:702-711. http://dx.doi.org/10.1016/j. foodchem.2013.03.035.

Haque, M. A., A. Putranto, P. Aldred, J. Chen, and B. Adhikari. 2013b. Drying and denaturation kinetics of whey protein isolate (WPI) during convective air drying process. Drying Technol. 31:1532-1544. http://dx.doi.org/10.1080/07373937.2013.794832.

Hong, S.-I., and J. M. Krochta. 2003. Oxygen barrier properties of whey protein isolate coatings on polypropylene films. J. Food Sci. $\quad 68: 224-228 . \quad$ http://dx.doi.org/10.1111/j.1365-2621.2003. tb14143.x.

Kitabatake, N., and E. Doi. 1991. Denaturation and texturization of food protein by extrusion cooking. Pages 361-372 in Food Extru- sion Science and Technology. J. L. Kokini, C.-T. Ho, and M. V. Karwe, ed. Marcel Dekker, New York, NY.

Maa, Y.-F., P.-A. T. Nguyen, and S. W. Hsu. 1998. Spray-drying of air-liquid interface sensitive recombinant human growth hormone. J. Pharm. Sci. 87:152-159. http://dx.doi.org/10.1021/js970308x.

Maté, J. I., and J. M. Krochta. 1996. Comparison of oxygen and water vapor permeabilities of whey protein isolate and $\beta$-lactoglobulin edible films. J. Agric. Food Chem. 44:3001-3004. http://dx.doi. org $/ 10.1021 /$ jf950595v.

McHugh, T. H., J.-F. Aujard, and J. M. Krochta. 1994. Plasticized whey protein edible films: Water vapor permeability properties. J. Food Sci. 59:416-419. http://dx.doi.org/10.1111/j.1365-2621.1994. tb06980.x.

Oldfield, D. J., M. W. Taylor, and H. Singh. 2005. Effect of preheating and other process parameters on whey protein reactions during skim milk powder manufacture. Int. Dairy J. 15:501-511. http:// dx.doi.org/10.1016/j.idairyj.2004.09.004.

Parris, N., and M. A. Baginski. 1991. A rapid method for the determination of whey-protein denaturation. J. Dairy Sci. 74:58-64. http://dx.doi.org/10.3168/jds.S0022-0302(91)78143-5.

Pauling, L. 1988. General Chemistry. Dover Publications, New York, NY

Pelegrine, D. H. G., and C. A. Gasparetto. 2005. Whey proteins solubility as function of temperature and $\mathrm{pH}$. Lebensm. Wiss. Technol. 38:77-80. http://dx.doi.org/10.1016/j.lwt.2004.03.013.

Perez-Gago, M. B., and J. M. Krochta. 2001. Denaturation time and temperature effects on solubility, tensile properties, and oxygen permeability of whey protein edible films. J. Food Sci. 66:705710. http://dx.doi.org/10.1111/j.1365-2621.2001.tb04625.x.

Pérez-Gago, M. B., P. Nadaud, and J. M. Krochta. 1999. Water vapor permeability, solubility, and tensile properties of heat-denatured versus native whey protein films. J. Food Sci. 64:1034-1037. http://dx.doi.org/10.1111/j.1365-2621.1999.tb12276.x.

Robertson, G. L. 2013. Food Packaging: Principles and Practice. 3rd ed. CRC Press, Boca Raton, FL.

Schmid, M. 2013. Properties of cast films made from different ratios of whey protein isolate, hydrolysed whey protein isolate and glycerol. Materials (Basel) 6:3254-3269.

Schmid, M., K. Dallmann, E. Bugnicourt, D. Cordoni, F. Wild, A. Lazzeri, and K. Noller. 2012. Properties of whey-protein-coated films and laminates as novel recyclable food packaging materials with excellent barrier properties. Int. J. Polym. Sci. 2012:562381. http://dx.doi.org/10.1155/2012/562381.

Schmid, M., F. Hammann, and H. Winkler. 2013a. Technofunctional properties of films made from ethylene vinyl acetate/whey protein isolate compounds. Packag. Technol. Sci. 27:521-533. http:// dx.doi.org/10.1002/pts.2051.

Schmid, M., L.-V. Hinz, F. Wild, and K. Noller. 2013b. Effects of hydrolysed whey proteins on the techno-functional characteristics of whey protein-based films. Materials (Basel) 6:927-940. http:// dx.doi.org/10.3390/ma6030927.

Schmid, M., K. Noller, F. Wild, and E. Bugnicourt. 2013c. Whey protein coated films. World Intellectual Property Organization (WIPO) Patent No. WO2013014493.

Schmid, M., S. Sängerlaub, L. Wege, and A. Stäbler. 2014. Properties of transglutaminase crosslinked whey protein isolate coatings and cast films. Packag. Technol. Sci. http://dx.doi.org/10.1002/ pts. 2071 